\title{
Kearifan Lokal Masyarakat di Kawasan Taman Taman Nasional Gunung Tambora dalam Memanfaatkan Sumber Daya Alam (study di Desa Kawinda To'i)
}

\author{
(The Local Arificity of The Community in The Kawasan Taman National Gunung \\ Tambora in Utilizing Natural Recources (study in Kawinda To'i Village)
}

\author{
Zulharman $^{1 *}$, Deni Prayadi \\ ${ }^{1}$ STKIP Taman Siswa Bima \\ ${ }^{2}$ Ikatan Alumni Kehutanan Universitas Muhammadiyah Malang \\ *Email: Zul one@yahoo.co.id
}

\section{Abstract}

The purpose of this research is to describe the relationship between the use of natural resources by the community and the socio-economic factors of the community in the Mount Tambora National Park area, to describe the form of natural resource use by the community in the Mount Tambora National Park area, and to describe the form of community local wisdom regarding resource utilization. natural. This research was conducted in the village of Kawinda To'i Kec. Tambora, Kab. Bima, West Nusa Tenggara Province, 15 October - 12 November 2018 with data collection methods using literary studies, interviews and observations, respondents were taken by purposive sampling, data analysis was carried out by qualitative descriptive analysis according to Singarimbun (2010). The results obtained, in the utilization of natural resources, the community uses water as a hydroelectric power plant, daily necessities, and a source of irrigation for agricultural land. Utilization of beaches and marine products with beaches where there are turtles and sea from fish caught by fishermen. Utilization of forest and forest products, timber forest products are used to make houses, fences, and household furniture. Nontimber forest products are used as animal feed, cooking ingredients and honey. Local wisdom in the use of natural resources in the village of Kawinda to'i, namely the kesambi tree as a determinant of the quality of honey, prohibition of hunting and Ngaha aina ngoho.

Key Words: kawinda To'i, Local wisdom, Mount Tambora National Park, non-forest products

\section{Intisari}

Tujuan dari penelitian untuk mendeskripsikan hubungan pemanfaatan sumberdaya alam oleh masyarakat dengan faktor sosial ekonomi masyarakat di kawasan Taman Nasional Gunung Tambora, Untuk mendeskripsikan bentuk pemanfaatan sumber daya alam oleh masyarakat di kawasan Taman Nasional Gunung Tambora, dan untuk mendiskripsikan bentuk kearifan lokal masyarakat terhadap pemanfaatan sumber daya alam. Penelitian ini dilaksanakan di desa Kawinda To'i Kec. Tambora, Kab. Bima, Proinsi Nusa Tenggara Barat, 15 Oktober - 12 November 2018 dengan metode pengambilan data secara studi literarur, wawancara dan observasi, responden diambil secara purposive sampling, analisa data dilakukan dengan analisa deskriptif kualitatif menurut Singarimbun (2010). Hasil yang di peroleh, dalam pemanfaatan sumber daya alam masyarakat memanfaatkan air sebagai pembangkit listrik tenaga air, kebutuhan sehari-hari, dan sumber pengairan bagi lahan pertanian. Pemanfaatan pantai dan hasil Laut dengan pantai yang dimana terdapat penyu dan laut dari ikan hasil tangkapan nelayan. Pemanfaatan hutan dan hasil hutan, hasil hutan kayu di gunakan untuk membuat rumah, pagar, dan perabotan rumah tangga. Hasil hutan non kayu di manfaatkan sebagai pakan ternak, bahan masak memasak dan madu. Kearifan lokal dalam pemanfaatan sumber daya alam di desa Kawinda to'i yaitu pohon kesambi sebagai penentu mutu madu, larangan berburu dan Ngaha aina ngoho.

Kata Kunci: hasil non hutan, kawinda To'i, Kearifan lokal, Taman Nasional Gunung Tambora 


\section{JOURNAL OF FOREST SCIENCE AVICENNIA}

E-ISSN : 2622-8505 | Email : avicennia kehutananumm@umm.ac.id http://ejournal.umm.ac.id/index.php/avicennia

O Jl. Raya Tlogomas No.246 Malang, Jawa Timur (Febri)

\section{PENDAHULUAN}

Kelestarian kawasan hutan dan kehidupan masyarakat tradisional yang hidup di dalam dan sekitarnya saling mepengaruhi. Dengan kata lain, kelestarian kawasan hutan sangat dipengaruhi oleh kehidupan masyarakat tradisional. Begitupun dengan kelompok masyarakat, mereka sangat bergantung pada sumber daya alam dan kondisi lingkungan di kawasan hutan tersebut. Mereka berusaha mengenali, memahami, dan menguasai alam agar mampu memanfaatkannya seoptimal mungkin guna memenuhi kebutuhan hidup mereka.

Kearifan lokal merupakan kearifan lingkungan dalam bentuk tata nilai atau perilaku hidup dalam bermasyarakat di suatu tempat atau daerah, baik antar sesama masyarakat maupun dalam berinteraksi dengan lingkungan mereka. Kearifan lokal adalah semua bentuk pengetahuan, keyakinan, pemahaman, atau wawasan serta adat kebiasaan atau etika yang menuntun perilaku manusia dalam kehidupan di dalam komunitas ekologis. Semua bentuk kearifan lokal ini dihayati, dipraktikan, diajarkan, dan diwariskan dari generasi ke generasi sekaligus membentuk pola perilaku manusia terhadap sesama manusia, alam, ataupun gaib. Kerusakan alam tidak hanya ditanggung oleh manusia, tetapi juga memiliki dampak terhadap makhluk lain. Istimewanya, manusia dan kebudayaannya memiliki kelenturan ekologis yang tinggi, tetapi makhluk hidup lainnya terancam punah karena kerusakan habitat (Francis, 2005). Hasil identifikasi tahun 2013 ditemukan sebanyak 277 spesies dan famili pohon, herba, perdu, epifit dan liana. Ditemukan juga spesies endemik Elaeocarpus batudulangii yang merupakan tumbuhan khas di kawasan Gunung Tambora, selain itu ditemukan juga beberapa jenis tumbuhan kunci/ penting pembentuk ekosistem klimak di kawasan Gunung Tambora, antara lain : Cemara gunung (Casuarina junghuniana); Rajumas (Duabanga moluccana); Ganitri (Elaeocarpus sphaericus); Engelhardtia spicata (Maksimus, 2015).

Tujuan dari penelitian untuk mendeskripsikan hubungan pemanfaatan sumberdaya alam oleh masyarakat dengan faktor sosial ekonomi masyarakat di kawasan Taman Nasional Gunung Tambora, Untuk mendeskripsikan bentuk pemanfaatan sumber daya alam oleh masyarakat di kawasan Taman Nasional Gunung Tambora, dan untuk mendiskripsikan bentuk kearifan lokal masyarakat terhadap pemanfaatan sumber daya alam.

\section{METODE PENELITIAN}

\section{Tempat dan Waktu Penelitian}

Penelitian dilaksanakan di Desa Kawinda To'i Kecamatan Tambora Kabupaten Bima. Adapun waktu penelitian dilakukan pada bulan Oktober - November 2018.

\section{Alat dan Bahan Penelitian}

Alat yang digunakan adalah alat tulis menulis, panduan wawancara, tape recorder, Laptop, peta, dan kamera sedangkan bahan yang di gunakan dalam penelitian ini adalah data-data dokumen pendukung penelitian seperti data demografi dan lahan. 


\section{JOURNAL OF FOREST SCIENCE AVICENNIA}

E-ISSN : 2622-8505 | Email : avicennia kehutananumm@umm.ac.id http://ejournal.umm.ac.id/index.php/avicennia

Pl. Raya Tlogomas No.246 Malang, Jawa Timur (\$ 0822-5785-2386 (Febri)

\section{Pelaksanaan Penelitian Tahapan Penelitian}

Penelitian yang dilakukan dengan tujuan untuk mengetahui apa saja kearifan lokal masyarakat Desa Kawinda To'i dalam memanfaatkan sumber dayanya terdiri dari 3 tahap yaitu :

a. Studi Pustaka/literatur

b. Kajian lapang

c. Pengelolaan dan analisis data sesuai tahap 1 dan 2

\section{Pengumpulan Data}

\section{a. Kajian Literatur}

Kajian literatur bertujuan untuk mendapatkan data-data yang berkaitan dengan sejarah masyarakat Kawinda To'i secara umum, data mengenai penduduk atau demografi desa, luas Desa, data mengenai lahan serta sejarah penggunaan lahan yang dilakukan oleh masyarakat Desa Kawinda To'i. Studi literatur ini dapat menggunakan buku, tulisan atau artikel, koran atau tulisan lainya yang berkaitan dengan deskripsi masyarakat Kawinda To'i.

\section{b. Kajian Lapangan}

Kajian lapangan dilaksanakan melalui kegiatan wawancara dan pengamatan terlibat.

\section{c. Wawancara}

Pengumpulan informasi dilakukan dengan menggunakan teknik aksidental sampling, yang dimana penentuan sampel diambil secara kebetulan, yaitu siapa aja yang secara kebetulan bertemu dengan peneliti dapat digunakan sebagai sampel, bila dipandang orang yang kebetulan ditemui itu cocok sebagai sumber data (Sugiono, 2001).

\section{d. Terlibat}

\section{Partisipatif)}

Peneliti mengumpulkan data dengan cara mengamati aktivitas masyarakat baik yang berupa kebiasaan keseharian maupun aktivitas khusus. Selain itu peneliti juga mengamati berbagai macam hal lain yang dapat ditangkap oleh panca indera peneliti seperti lingkungan fisik tempat aktivitas masyarakat berlangsung.

\section{Analisa data}

Analisa data menggunakan alalisa deskriptif kualitatif mengikuti kaidah analisa data deskriptif kualitatif menurut Singarimbun (2010).

\section{HASIL DAN PEMBAHASAN}

\section{Gambaran Umum Lokasi}

\section{a. Letak dan Luas Kawasan}

Secara geografis kelompok hutan Gunung Tambora terletak diantara 1170 $47^{\prime} 00^{\prime \prime}$ sd 1180 17'00" BT dan 080 07'00" LS. Cagar Alam, Suaka Margasatwa maupun Taman buru masuk dalam wilayah pemerintahan Kabupaten Bima dan Kabupaten Dompu. Sebelah utara kawasan ini berbatasan dengan hutan produksi dan areal peruntukan lainnya, sebelah selatan berbatasan dengan hutan produksi, hutan lindung dan hutan produksi terbatas, sebelah barat berbatasan dengan areal peruntukan lainnya dan hutan produksi sedangkan sebelah timur berbatasan dengan hutan produksi (Setyawan, 2012). Desa Kawinda To'i memiliki luasan wilayah sebesar 407,63 km². Batas wilayah Desa Kawinda To'i, batas timur berbatasan dengan Desa Oi Katupa, dan batas barat berbatasan dengan Desa Mpada. Desa Kawinda to'i adalah Desa yang memiliki luasan terbesar dari Desa lainnya di Kecamatan Tambora.

\section{Topografi}

Kawasan konservasi Gunung Tambora memiliki topografi berbukit sampai bergunung dengan kelerengan agak landai sampai curam dengan klasifikasi kelas kelerengan $8 \%$ - 45\% (Valiara, 2015). 


\section{JOURNAL OF FOREST SCIENCE AVICENNIA}

E-ISSN : 2622-8505 | Email : avicennia kehutananumm@umm.ac.id http://ejournal.umm.ac.id/index.php/avicennia

O Jl. Raya Tlogomas No.246 Malang, Jawa Timur 0822-5785-2386 (Febri)

\section{Geologi dan Tanah}

Kawasan hutan Gunung Tambora memiliki formasi geologi yang sangat dipengaruhi oleh aktifitas vulkanologi Gunung Tambora yang sebagian besar terdiri dari batuan hasil Gunung api dan sebagian kecil batuan Gunung api tua. Jenis tanah di kawasan hutan Gunung Tambora terdiri dari Regosol (volkan), Mediteran (volkon) dan aluvial (daratan) yang mempunyai sifat sangat peka terhadap erosi dan sangat labil (Valiara, 2015).

Menurut klasifikasi Schmicht \& Ferguson Gunung Tambora memiliki cakupan wilayah yang sangat luas memiliki 3 tipe iklim yaitu tipe iklim $D$ dengan nilai $Q$ antara $60 \%-100 \%$, tipe iklim E dengan nilai Q antara $100 \%$ - $167 \%$ dan tipe iklim $F$ dengan nilai Q antara $167 \%$ - 300 (Valiara, 2015).

\section{a. Data Kependudukan}

\begin{tabular}{lllll}
\hline \multirow{2}{*}{ No } & \multirow{2}{*}{ Dusun } & \multicolumn{2}{c}{ Jumlah Warga } & \multirow{2}{*}{ Jumlah KK } \\
\cline { 3 - 4 } & Kawinda & 135 & $\mathrm{P}$ & 102 \\
\hline 1 & Labau & 174 & 145 & 108 \\
\hline 2 & Katupa & 108 & 110 & 81 \\
\hline 3 & Dana Kala & 112 & 118 & 85 \\
\hline 4 & Oi Marai & 178 & 187 & 130 \\
\hline 5 & Sori Na'e & 249 & 216 & 160 \\
\hline 6 & & & &
\end{tabular}

Desa Kawinda To'i memiliki 5 dusun yang sudah di tetapkan dan 1 dusun yang belum tapi akan di tetapkan. 5 dusun yang disebutkan tersebut yaitu dusun Kawinda dengan jumlah kk 102, dusun Labau 108, dusun Katupa 81, dusun Dana kala 85, dusun Oi marai 130 dan Sori na'e 160 KK. Jumlah seluaruh warga desa Kawinda to'i yaitu 1882 jiwa.

\section{Sejarah dan Adat Desa}

\section{a. Sejarah Desa}

Wilayah yang sekarang adalah Desa Kawinda To'i dulunya yaitu wilayah dari kesultanan Tambora. Masyarakat asli Tambora sudah tidak ada sejak terjadinya letusan Gunung Tambora pada tahun 1815. Masyarakat Desa Kawinda to'i yang sekarang adalah para pendatang. Orang- orang yang datang dari luar, datang untuk bercocok tanam. Desa Kawinda to'i terbentuk pada tahun 1971. Dengan adanya aktifitas dari orang-orang yang bercocok tanam, maka para pendatang pun semakin bertambah, dari yang awal rumahnya berjauh-jauhan dan kemudian menjadi sebuah pemukiman sehingga lama-kelamaan terbentuklah sebuah desa.

\section{b. Adat Desa}

Masyarakat dahulu memiliki kebiasaan melakukan upacara ritual adat. Upacara ritual adat ini dilakukan ketika masyarakat ingin membuka lahan untuk dijadikan lahan pertanian. Masyarakat Desa mengumpulkan makanan dan uang untuk membeli bahan makanan lainnya, dan terkadang masyarakat mengumpulkan 
uang untuk membeli hewan sembelihan seperti kambing kemudian di olah menjadi sebuah makanan dan hidangan tersebut di nikmati bersama-sama. Acara ini dilakukan dengan maksud agar masyarakat diberikan keselamatan dan mengharapkan hasil panen kelak akan melimpah. Setelah upacara adat untuk keselamatan, maka akan diadakan upacara adat syukuran. Upacara adat syukuran ini dilakukan oleh masyarakat setelah panen. Acara syukuran ini dilakukan sebagai bentuk rasa syukur masyarakat desa kepada Tuhan yang telah memberikan rizki dalam bentuk hasil dari panen masyarakat.

\section{Pandangan Terhadap Sumber Air}

Air merupakan sumber kehidupan bagi kelangsungan hidup mahluk hidup. Sama halnya untuk penduduk Desa Kawinda To'i, penduduk menggunakan air untuk kebutuhan sehari-hari, seperti air minum, mandi dan mencuci. Pada awalnya penduduk menggantungkan kebutuhan airnya pada sumber air yang mengalir dari hutan, namun kini tiap rumah memiliki sumur ataupun mesin pompa air. Dengan adanya sumur atau mesin pompa air dapat mempermudah para warga desa untuk mendapatkan kebutuhan airnya.

\section{Pandangan Terhadap Hutan}

Kesadaran arti penting hutan bagi kehidupan keseharian mereka menyebabkan masyarakat desa Kawinda To'i melihat hutan bukan sebagai objek eksplorasi untuk memenuhi kebutuhan. Perilaku alam terhadap kehidupan mereka disadari sebagai konsekuensi dari sikap dan perbuatan mereka terhadap hutan dan lingkungan. Hal ini misalnya tercermin dari adanya upacara ritual adat, pada saat membuka hutan untuk keperluan perladangan. Upacara tersebut pada dasarnya dimaksudkan sebagai bentuk permohonan izin sekaligus pemohonan kepada para mahluk yang mediami hutan dan Gunung Tambora. Dengan upacara tersebut juga dimaksudkan agar kelak dikemudian hari tidak ada ganggunan terhadap tanaman diladang, baik berupa peyakit ataupun serangan hewan.

\section{Pemanfaatan Sumber Daya Alam}

\section{a. Pemanfaatan Air}

Kawinda To'i menyimpan banyak kekayaan alam, salah satunya terdapat air terjun dari Gunung Tambora. Masyarakat desa memanfaatkan aliran air sebagai sumber listrik Desa, yaitu dengan membangun turbin air atau PLTA (pembangkit listrik tenaga air). Turbin air ini dibangun untung memenuhi kebutuhan listrik masyarakat.

\section{b. Pemanfaatan Pantai dan Hasil Laut}

Hasil alam lainnya yang dimiliki desa dari laut yaitu telur penyu. Sepanjang pantai di Desa Kawinda to'i memiliki potensi tempat bertelurnya penyu. Sebagian lokasi pantai tempat bertelurnya penyu di kelola oleh Desa Kawinda To'i \pm 5 $\mathrm{km}$, dan yang lainnya di kelola oleh BKSDA NTB. Hasil lainnya yaitu ikan dari hasil tangkapan para nelayan. Ikan hasil tangkapan akan di jual dan di konsumsi sendiri. Mata pencaharian masyarakat sebagai nelayan sangat sedikit, masyarakat tidak berani karena kondisi laut disana adalah laut lepas dengan ombak yang cukup besar. 


\section{c. Pemanfaatan Hutan dan Hasil Hutan}

\section{Hasil hutan kayu}

Hutan sebagai sumber penghidupan, dan hasil dari hutan dapat dimanfaatkan untuk memenuhi beberapa macam kebutuhan. Masyarakat Desa Kawinda To'i memanfaatkan hasil hutan kayu dan digunakan untuk membangun rumah, membuat perabotan rumah tangga seperti kursi dan meja dan juga sebagai kayu bakar untuk kegiatan masak-memasak.

\section{Hasil hutan non kayu}

Hasil hutan non kayu sering dimanfaatkan oleh masyarakat Desa Kawinda To'i untuk kebutuhan sehari-hari dan juga untuk meningkatkan perekonomiannya. Pemanfaatan hasil hutan non kayu oleh masyarakat untuk kebutuhan sehari-hari seperti pakan hewan ternak dan kayu bakar untuk kegiatan masak-memasak. Hasil hutan non kayu yang selalu dan masih dimanfaatkan oleh masyarakat untuk meningkatkan perekonomian yaitu madu. Hasil hutan non kayu yang sangat terlihat pada masyarakat Desa Kawinda To'i yaitu madu. Mencari madu merupakan mata pencaharian kebanyakan dari masyarakat Desa Kawinda To'i. Madu bisa dikatan sebagai komoditi utama untuk peningkatan ekonomi masyarakat desa.

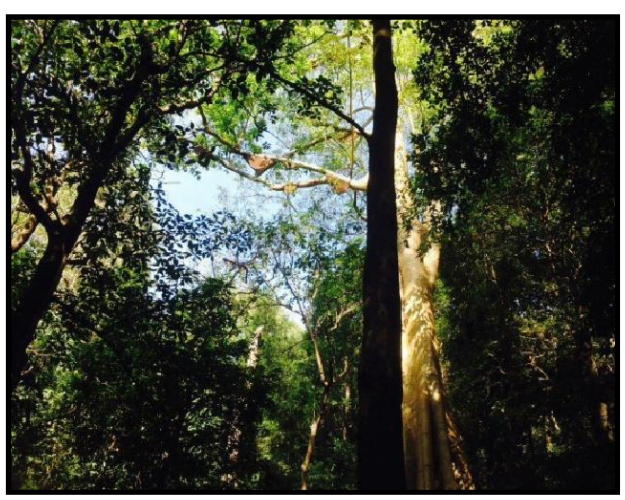

Gambar 1. Pohon Owo/Sialan empat bersarangnya madu hutan

\section{Kearifan Lokal dan Masyarakat}

\section{a. Pohon Kesambi Penentu Mutu Madu}

Pohon kesambi banyak tersebar di sekitaran kawasan Taman Nasional Gunung Tambora. Di Desa Kawinda To'i, pohon kesambi banyak tersebar dan termasuk yang berpengaruh untuk menentukan kualitas madu. Pohon kesambi dapat menentukan kualitas madu pada musim-musim tertentu dan menghasilkan madu lebih banyak, seperti ketika pohon kesambi berbunga.

Tidak ada peraturan larangan untuk menebang pohon kesambi, hanya saja masyarakat yang mengetahui bahwa pohon kesambi sangat berpengaruh pada kualitas madu menganjurkan untuk tidak menebangnya. Pohon kesambi tumbuh di sekitar desa, oleh karena itu masyarakat pun merasa memiliki hak untuk menebang pohon tersebut. Dengan keadaan demikian, pihak desa sering melakukan 


\section{JOURNAL OF FOREST SCIENCE AVICENNIA}

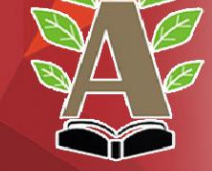

E-ISSN : 2622-8505 | Email : avicennia kehutananumm@umm.ac.id

http://ejournal.umm.ac.id/index.php/avicennia

○ Jl. Raya Tlogomas No.246 Malang, Jawa Timur 0822-5785-2386 (Febri)

sosialisasi pada masyarakat utuk tidak menebang pohon terutama kesambi, karena pohon kesambi merupakan penentu mutu madu pada musim-musim tertentu.

\section{b. Larangan Berburu}

Desa Kawinda to'i banyak memiliki kekayaan alam. Masyarakat desa Kawinda to'i merasa bahwa semua kekayaan alam yang di miliki adalah anugrah dan titipan dari Tuhan, oleh sebab itu harus di jaga dan di lestarikan agar generasi berikutnya juga dapat merasakan kekayaan alam yang di berikan oleh Tuhan. Dalam hal ini pemanfaatan yang dilakukan Desa Kawinda to'i dengan adanya larangan dalam berburu untuk melindungi sebagai pengendalian hama terhadap tanamantanaman yang terdapat di kawasan sekitar Desa, pembinaan populasi dan pembinaan habitat, Segingga kawasan di sekitar Desa tetap terjaga dan tidak merubah tatanan ekosistem yang sudah terjaga sejak lama.

\section{c. Kearifan Ngaha Aina Ngoho}

Masyarakat desa Kawinda to'i memiliki budaya bercocok tanam dengan ladang berpindah. Ternyata hal ini dirasakan dapat membawa dampak negatif berupa kerusakan lingkungan hidup. Pada pertengahan tahun 1980, maka lahirlah "ngaha aina ngoho" yang berarti larangan untuk melakukan perladangan liar. Ungkapan ini bermakna nasehat untuk hidup hemat dalam arti luas. Berhemat dalam segi ekonomi, berhemat dalam menggunakan sumberdaya alam untuk kehidupan di masa mendatang bagi yang hidup saat ini dan anak cucu.

\section{KESIMPULAN}

Berdasarkan dari data dan analisis data serta pembahasan dari hasil penelitian, maka dapat di peroleh kesimpulan sebagai berikut : Mata pencaharian masyarakat Desa Kawinda To'i kebanyakan sebagai pencari madu hutan, dari jumlah jiwa 1882, 1502 orang atau $80 \%$ mata pencaharian sebagai pencari madu. Sumber daya alam yang dimanfaatkan yaitu : a) Air Kebutuhan sehari-hari, Pengairan, PLTA (pembangkit Listrik tenaga Air). b) Hasil Hutan Kayu : rumah, pagar, prabotan rumah, meja, kursi,tangga. c) Hasil Hutan Non Kayu : Madu sebagai komoditi utama dalam peningkatan ekonomi masyarakat. d) Hasil laut dan pantai : pantai di desa berpotensi sebagai tempat bertelurnya penyu dan juga ikan-ikan hasil tangkapan nelayan. Kearifan lokal masyarakat : a) Pohon kesambi tidak boleh di tebang karena pohon kesambi penentu mutu madu. b) Larangan berburu karena sebagai pengendalian hama bagi tanaman, pembinaan populasi, dan habitan sehingga tidak merubah tatanan ekosistem Di sekitar Desa yang sudah terbentuk sejak lama. c) Kearifan Ngaha aina ngoho maksudnya agar masyarakat tidak serakah dalam mengambil hasil alam, agar kelak dapat dirasakan juga oleh anak cucu

\section{Saran}

Ketika peneliti melakukan penelitian di Desa Kawinda To'i, masyarakat meresahkan pemanfaatan air, masyarakat Desa tidak tau mau manfaatkan untuk apa lagi air yang melimpah di Desa Kawinda. Peneliti menyarankan untuk membuat tambak kecil-kecilan untuk ikan, dan tempat wisata di area sekitar air terjun. Ikan dapat di konsumsi sendiri dan juga dapat di jual untuk meningkatkan ekonomi masyarakat. 


\section{JOURNAL OF FOREST SCIENCE AVICENNIA}

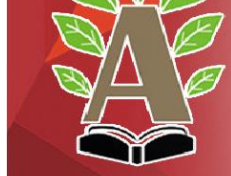

E-ISSN : 2622-8505 | Email : avicennia kehutananumm@umm.ac.id http://ejournal.umm.ac.id/index.php/avicennia

O Jl. Raya Tlogomas No.246 Malang, Jawa Timur (Febri)

\section{Daftar Pustaka}

Andrietha. 2013. Pengelolaan Sumber Daya Alam. Online. http://andrietha. blogspot.co.id/2013/04/pengelolaa n-sumber-daya-alam.html. Akses 20 Januari 2017.

Annonymous. 2013. Pengertian Sumber Daya Alam. Online. http://iwakpithik.blogspot.co.id/2013/01/peng ertian-sumber-daya-alamdan.html. Akses 25 Januari 2017

Asyari, S.I. 1983. Pengantar Sosiologi. Usaha Nasional. Surabaya

Bratmihardja, M. 1987. Pembinaan Kelembagaan Dalam Pembangunan Taman Nasional. Buletin Persaki

Francis Wahono, 2005.Pangan, Kearifan Lokal dan Keanekaragaman Hayati. Penerbit Cindelaras Pustaka Rakyat Cerdas. Yogyakarta

Kartini, K. Psikologi Umum. Penerbit Alumni. Bandung

Keli, Maksimus. 2015. Potensi Gunung Tambora. Online. http://forestmaxs.blogspot.co.id/2015/06/pote nsi-gunung-tambora.html. Akses 23 September 2016

Malingi Alan. 2011. Kehidupan di Lereng Tambora. Online. https://alanmalingi. wordpress.com/2011/05/07/kehidu pan-di-lereng-tambora/. Akses 23 September 2016.

Manan, S. 1997. Hutan Rimbawan Dan Masyarakat. IPB Press. Bogor
Nasendi. 1986. Pengelolaan Buffer zone Taman Nasional dan Cagar Alam Melalui Konsep Social Forestry. Makalah pada Lokarya Taman Nasional. Bunga Rampai Perhutanan Sosial (Social Forestry). Administrator Program Perhutanan Sosial Pusat-Direktorat Jendral Pengusahaan Hutan. Cisarua, Bogor, 5-7 Februari 1986.

Oldfield, S. 1988. Buffer Zone Management in Tropical Moist Forests : Case Studies and Guidelines. International Union For Conservation of Nature and Natural Resources.

Purnomohadi, S. $1985 . \quad$ Sistem Pengetahuan Tradisional Masyarakat di Sekitar Kawasan Hutan Lindung Gunung Lumut, Kab. Pasir Provinsi Kalimantan Timur. Kajian: Pemanfaatan Tumbuhan. Skripsi. Bogor: Fakultas Kehutanan Institut Pertanian Bogor

Setyorini, P Virna. 2015. Kawasan Tambora Layak Jadi Taman Nasional. Online. http://www.antaranews.com/berita 4495857/kawasan-tambora-layakjadi-taman-nasional. Akses 9 Desember 2016.

Soekmadi, R. 1990. Tata Pemerintahan dan Administrasi Desa. Badan Perencana Pembangunan Daerah Tingkat II, Kabupaten Bogor. Bogor

Sony Keraf, 2006. Etika Lingkungan. Kompas, Jakarta

Sugiono, 2008. Metode Penelitian Kuantitatif dan R\&D. Bandung : Penerbit Alfabeta. 


\section{JOURNAL OF FOREST SCIENCE AVICENNIA}

E-ISSN : 2622-8505 | Email : avicennia.kehutananumm@umm.ac.id http://ejournal.umm.ac.id/index.php/avicennia

○ Jl. Raya Tlogomas No.246 Malang, Jawa Timur 0822-5785-2386 (Febri)

Valiara, 2015. Potensi Gunung Tambora. Online. http://forest-maxs.blogspot .co.id/2015/06/potensi-gunung tambora.html. Akese 05 Januari 2017. 


\section{JOURNAL OF FOREST SCIENCE AVICENNIA}

E-ISSN : 2622-8505 | Email : avicennia.kehutananumm@umm.ac.id http://ejournal.umm.ac.id/index.php/avicennia

P Jl. Raya Tlogomas No.246 Malang, Jawa Timur (Febri)

Wikipedia. 2015. Taman Nasional Gunung Tambora. Online. https://id. wikipedia.org/Taman Nasional Gu Wikipedia. 2016. Hasil Hutan Non Kayu. Online. https://id.wikipedia.org/. Akses 12 Januari 2017. nung Tambora. Akses September 2015.

Wikipedia. 2016. Menggeris. Online. https://id.wikipedia.org/wiki/Meng geris. Akses 12 Januari 2017 